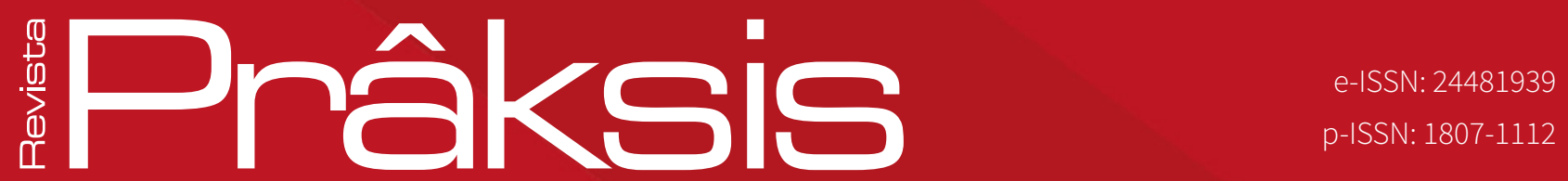

Recebido em: 18 de fevereiro de 2018

Aprovado em: 15 de junho de 2018

Sistema de Avaliação: Double Blind Review

RPR |a. 15 |n. 2 |p. 146-159|jul./dez. 2018

DOI: https://doi.org/10.25112/rpr.v2i0.1659

\title{
Da diáspora à asCeNsão pOÉtICA dO SUJEITO KNOPFLIANO
}

\section{DE LA DIÁSPORA A LA ASCENSIÓN POÉTICA DEL SUJETO KNOPFLIANO}

\section{Paula Terra Nassr}

Doutora em Literatura Luso-africana (Universidade Federal do Rio Grande do Sul/Brasil).

Professora de Língua Espanhola na SMED (Porto Alegre/Brasil).

E-mail: paulanassr@gmail.com. 


\section{RESUMO}

As terras africanas passaram por um momento histórico de sofrimento, silenciamento e submissão no período em que vigia o colonialismo, época essa que fez emergir sujeitos híbridos. Este artigo apresenta a obra poética de Rui Knopfli, poeta moçambicano, que produziu seu discurso poético como uma forma de escapar à permanente sensação de diáspora e melancolia que o acompanhou em sua trajetória e marcou as bases de sua historicidade. Observamos em seus poemas a permanência de um sujeito cindido, que luta para fugir do silenciamento imposto pelos períodos colonial e revolucionário anticolinialista.

Palavras-chave: Rui Knopfli. Poema. Literatura moçambicana. Silêncio.

\section{RESUMEN}

Las tierras africanas pasaron por un momento histórico de sufrimiento, silenciamiento y sumisión en el período en que perduró el colonialismo, época que hizo emerger sujetos híbridos. Este artículo presenta la obra poética de Rui Knopfli, poeta mozambiqueño, que produjo su discurso poético como una forma de escapar a la permanente sensación de diáspora y melancolía que lo acompañó en su trayectoria y marcó las bases de su historicidad. Observamos en sus poemas la permanencia de un sujeto escindido, que lucha para huir del silenciamiento impuesto por los períodos colonial y revolucionario anticolinialista. Palabras-clave: Rui Knopfli. Poema. Literatura mozambiqueña. Silencio. 


\section{CONSIDERAÇÕES INICIAIS}

A obra poética do escritor Rui Knopfli nunca se apresentou dentro dos critérios em que se costumava enquadrar as produções poéticas conhecidas na década de 50, bem como não estava dentro da expectativa local de uma doutrinação crítica que regia a estética da poesia moçambicana. 0 poeta nasceu em 1932, em Inhambane, foi criado e educado em Lourenço Marques. O que não poderiam negar os críticos era que, civilmente, e sem dúvida alguma, ele era um escritor de Moçambique. Knopfli não seguia a rota definida que the queriam impor, nem escrevia ao sabor das massas à época do nacionalismo moçambicano nascente. $O$ conjunto da sua poética permite-nos compreender um discurso de um poeta que tem como pátria a língua portuguesa.

Oito anos antes de Moçambique ser elevado à condição de Província Ultramarina pelo império de Salazar, em 1951, e três anos antes de Eduardo Mondlane fundar a FRELIMO (Frente de Libertação de Moçambique), em 1962, o autor publica seu primeiro livro, 0 País dos outros, em 1959, em um momento político que todo o território africano vivia em efervescente luta contra a máquina colonizadora abastecida pela Europa.

Nessa primeira obra, observamos uma aguçada sensibilidade de captação do cotidiano, evidenciando um lirismo que desnuda emoções em um processo que revela o pacto do poeta com a língua portuguesa e com um tom, muitas vezes, melancólico, angustiante, ao expressar as durezas de um período histórico de silenciamento. Já no primeiro poema, apresenta-nos um "céu de chumbos e baionetas caladas", em que o pensamento vai aduzir a voz que cala na garganta e um "banquete da morte impossível." 0 autor segue em sua obra poética a linha de desconfigurar o discurso instituído, mesclando o trivial com o sublime, metaforizando sobre o espaço e o tempo que representam a sua tão amada ilha Muipíti - a ilha de Moçambique, principalmente, em seu livro publicado em 1972 - A ilha de Próspero.

Dentro de todas as influências culturais em que transitou, fez uso da temática da terra, com a ligação do homem e o meio. Assim o fez ao cantar em versos o seu vínculo com sua pátria, com a africanidade que soube expressar. A poesia knopfliana pode ser entendida se a situarmos em uma matriz de pensamento e influências europeias, mas não deixando de considerar o ponto de vista das vivências e experiências culturais, também, de origens africanas.

A imagem do rio e do vento mostram-nos um sujeito em constante devir, ambos circulam, ambos fluem. No livro 0 País dos outros, no fragmento do poema Lírica para uma ave (KNOPFLI, 2003, p. 37), temos estes versos bem significativos: "Na hora/ da aurora,/ gemem ventos,/ fluem surdos rios. Essas imagens da água e do vento, na poética knopfliana, aparecem como elementos condutores de um universo em que sussurram os conflitos históricos e se revelam os conflitos cotidianos, internos, de um sujeito que está à margem, situando-se ora no universo ocidental europeu, ora no universo africano. 
O sujeito poético vai, ao largo dos muitos versos, desvelar um tom confessional, mesclando, muitas vezes, ironia e sarcasmo como meio estilístico de disfarçar a angústia e a melancolia que o acompanham na jornada de luta contra o silenciamento. Busca uma imagem anódina nas paisagens, em uma lembrança da família ou da infância. Nos versos, contudo, veremos uma recorrência de imagens que metaforicamente revelam as sombras, o silêncio de um passado que não lhe dá sossego. Neste estudo, pretendemos evidenciar como o sujeito lírico de Knopfli transita entre o silêncio histórico e a voz produtora de um efeito de sentido subjetivado. Como base teórico-crítica, apoiaremo-nos em Eni Orlandi, Homi Bhabha, Marc Augé, Octavio Paz e George Steiner.

\section{DA MATERIALIDADE POÉTICA DE KNOPFLI}

A obra de Rui Knopfli vai falar daqueles sujeitos que, como ele, tiveram que se distanciar de seu espaço, de seus entes queridos, de suas paisagens e vivem da memória para se reconfortarem: "Eu aqui mordo-me de lembranças/ e saudades". Vemos uma poesia que é sobre um memorial da sua história privada, mas ao mesmo tempo, de uma história coletiva. Por não ser favorável ao sistema colonialista e não ser considerado um poeta plenamente engajado nas lutas de libertação, é um escritor deslocado em terras africanas e, ademais, por inspirar-se na cultura europeia, passa a ser visto como um estranho, alguém que não se orienta pela ordem dos demais poetas, seus contemporâneos.

Através do disfarce atrás de cada poema, esse sujeito pode fugir; através das imagens poéticas, de toda contradição histórica, é capaz de enfrentar o desafio do tempo e do espaço divididos entre um passado e uma atualidade. Ao cumprir-se o destino, que já vinha pressentindo desde os seus primeiros poemas, o da cisão, o da separação do seu espaço, o sujeito vai recorrer ao poder da palavra como forma de sobrevivência da própria identidade. Vai buscar na palavra a sustentação de seu estar no mundo.

Knopfli procura um apuramento verbal, por acreditar ser a supremacia de um discurso poético, ao mesmo tempo que se mostra um grande leitor de poetas brasileiros e europeus, como João Cabral de Melo Neto, Carlos Drummond de Andrade, Vinícius de Moraes, Manuel Bandeira, Fernando Pessoa, Mario de Sá Carneiro, T. S. Eliot, incluindo em suas preferências Shakeaspeare e muitos outros, dos quais buscará muito de sua estética.

O conjunto poético do poeta moçambicano apresenta versos ordenados e bem estruturados, sintaticamente, em que o discurso que completa essa ordem linguística é o da descoberta da voz interior. Compreender a si e as coisas do mundo é a missão do poeta. No meio da conjuntura dos mundos interior e exterior e na estruturação dos diversos códigos culturais, é que surge a palavra, se forma o poema e se materializa o imaginário do deslocamento do sujeito. Nesse processo, contudo, nem sempre o dizível irá satisfazer, não há modos de articulação, é então que o indizivel domina o espaço da criação. 0 silêncio 
entra em cena para invocar o passado, para servir de momento de pausa e reflexão. A memória das vivências em África, principalmente, no espaço de Moçambique, vai constituir outra faceta do poeta, em que as emoções de um tempo bom e de descoberta são revividas e representadas em cada verso.

As metáforas e as imagens utilizadas no poema vão apresentar tanto o espaço habitado de sentido no passado e rememorado, quanto o presente que serve de conforto para o lócus já não mais ocupado de fato, mas permeado pela memória. 0 processo no qual há uma evocação de um tempo e de um espaço são descritos nos poemas com bastante acuidade: "Erguido sobre altos pilares de cimento/ tinha vida própria o casarão:/ a sua voz era a dos eucaliptos/ e do mar, o crepitar leve da areia/ nas vidraças [...] (KNOPFLI, 2003, p. 301). O sujeito poético mostra-nos, em um tempo pretérito e com detalhes, o espaço por onde viveu suas experiências - o espaço africano, com suas paisagens, rios e mar. Dessa maneira, pode, no exílio, criar sensações de acolhimento, e seu discurso se reveste de significações repletas de memória.

No exílio, vemos uma obra que se mostra mais reveladora de uma transitoriedade do tempo, das coisas e da vida mergulhadas em dores. A situação do sujeito exilado, nesse período em que Knopfli estava produzindo parte da sua obra, sobretudo, durante o período das guerras de libertação (19611975), era de um "não lugar", tanto no seu espaço de origem, quanto nos espaços que abrigaram os exilados. Esse "não lugar" é um espaço, consoante Augé (1997, p. 169), no qual nem a identidade, nem a relação entre seres e realidades e nem a história são simbolizados.

As experiências individuais convertem-se em experiências literárias também no espaço do exílio, a vida e sua representação passam a se mesclar de modo que podemos observar que as fronteiras entre 0 espaço de escrita biográfica e matéria literária são diluídas. Por isso, o sujeito poético da obra knopfliana e o sujeito poeta não podem ser distinguidos como sujeitos diferentes, não se enquadra na situação de descontinuidade entre a obra literária e a biografia autoral.

No poema Proposição (KNOPFLI, 2003, p. 377), o sujeito poético nos diz: "Escrevendo, escrevo-me"; o fragmento sintetiza a subjetividade do poeta que emerge somada a sua escrita, que é representação da história junto com a poesia. Ambas são motivo e espaço de sobrevivência e transformação para o poeta. A poesia é, na obra de Knopfli, o espaço entre a experiência biográfica e a produção literária, é o testemunho e, ao mesmo tempo, produção de sentidos. Percebemos um sujeito híbrido, produto das mesclas de culturas, da influência ocidental e das influências africanas. Não há como haver uma pureza no produto cultural a partir da permeabilidade de culturas e histórias em um período no qual houve influência do discurso colonialista e do discurso africanista nacionalista. Ademais, havia a influência da cultura aborígene, de forte ascendência, que perpetuava a cultura via oralidade. A obra que se gesta nesse entremeio é riquíssima em diversidade, operando estratégias de permeabilidade cultural. 
Por todas as especificidades que uma obra pode apresentar em um espaço histórico, como o espaço em que estava imbricada a obra poética knoplifiana, é que podemos observar que nela existe, mesmo havendo uma importante preocupação com a palavra, um discurso que busca, no silêncio, um espaço para criação, uma forma de fugir ao silenciamento imposto pelo contexto histórico e pelas adversidades, no qual os sentidos vão se instalar como forma de superação e sobrevivência dentro de um espaço e tempo tão inconstantes.

\section{ENTRE O SILÊNCIO E A VOZ, ENTRE A SOMBRA E A LUZ}

A temática do silêncio percorre toda obra poética knopfliana, representada por sinônimos e metáforas que vão intensificar esse entrelaçamento de sensações que evidenciam o silenciamento imposto pelo sistema colonial. Nos versos, vemos o desejo de libertar sua íntima voz, bem como todas as vozes abafadas pela opressão colonialista. No poema Lírica para uma ave, que inaugura a sua primeira publicação, 0 país dos Outros, podemos observar que havia uma antecipação dos tempos de confronto e de rompimento de vozes, pois o poema vem a ser publicado em 1959, antes da eclosão das lutas de libertação, bem como pressagia os tempos complicados que viriam com a pós-libertação de Moçambique.

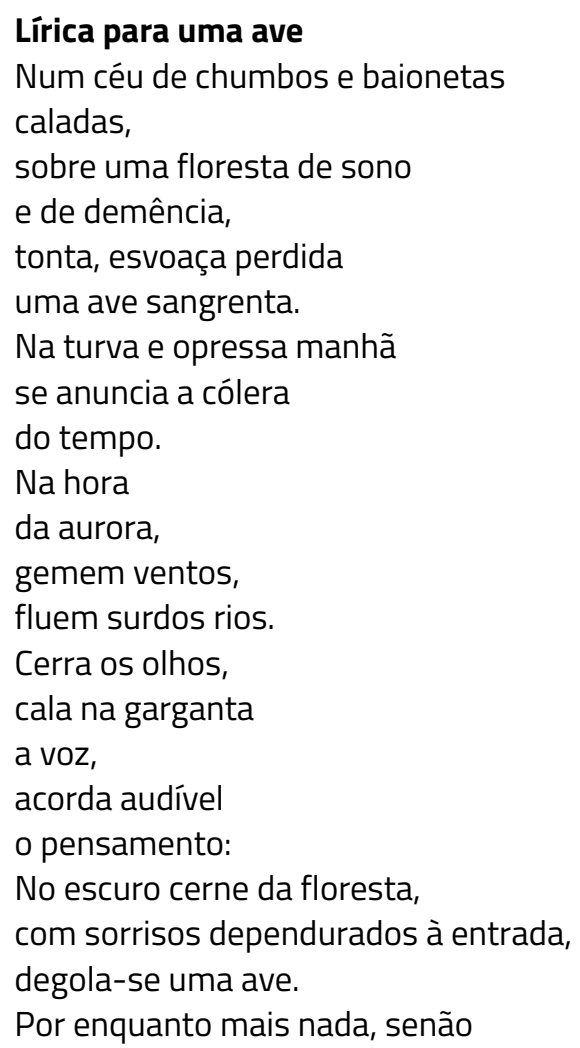


o torvo tinir dos talhares

no banquete da morte impossível. (KNOPFLI, 2003, p. 83).

Com essa "voz calada na garganta", o sujeito poético segue denunciando o medo do sistema opressor que não permite ser contrariado, que não deixa o outro ser como é, muito menos lhe permite seguir suas ideias e sua cultura. No poema $A$ Quinta Década, os versos retratam esse medo que perdurou por anos nas mentes dos sujeitos africanos e em todos os sujeitos que não eram coniventes com o processo destrutivo do sistema colonial.

\section{A Quinta Década}

Faz muitos anos que me oculto, quedo, estendido ao longo desta muralha. Infectas as feridas são vivas e secam em falso oblongas crostas.

Estendido em silêncio e torpor:

Vinte e tantos anos de idade e outros tantos de medo.

O medo da palavra e do gesto, medo na aba do chapéu e na gabardina, medo de ti que me olhas na avenida, medo escorrido ao longo da fachada, mergulhado nas poças brilhantes do asfalto. Não tenho culpa de ter medo, nasci do tempo impreciso do medo.

Não temo o rosto diverso da morte, não temo a ameaça da nuvem atómica, não temo o susceptível de ser temido há dois mil e tantos anos.

Temo a disfarçada ameaça indisfarçada, temo o honor da angústia a todo a hora, temo o temor do tempo do medo.

0 medo infla, cresce e avoluma-se. Impregna-se na carne, no cerne das unhas, veste a tepidez da epiderme e o frio dos ossos. Total, domina, obstrui, materializa-se em suor. Pela calada sombria vireis na hora próxima. Prevenido de medo, farto de medo, tremo, e este modo é uma ameaça que se oblitera e volta contra vós. (KNOPFLI, 2003, p. 86-87). 
O medo fez silenciar, mas a poesia pode nascer do momento de contemplação, a observação é um ato inteligente em momentos históricos opressores. Consoante Steiner,

Es preferible que el poeta se corte la lengua a que ensalce lo inhumano, ya sea por medio de su apoyo o de su incuria. Si el régimen totalitario es tan eficaz que cancela toda posibilidad de denuncia, de sátira, entonces que calle el poeta [...] la palabra no debe tener vida natural, no debe tener un santuario neutral en los lugares y en el tiempo de la bestialidad. El silencio es una alternativa. Cuando en la polis las palabras están llenas de salvajismo y de mentira [...]. (STEINER, 2003, p. 72).

No discurso knopfliano, a palavra denunciante vem em forma de versos, primeiro vem o silêncio contemplador, depois vem a manifestação, que ao falar do silêncio, do medo, das sombras que foram impostos pelo processo histórico, mostra o quanto o sujeito poético quer romper com esse silenciamento, quer resistir e mostrar que as vozes ciciadas têm o direito de serem invocadas. Que tempos tristes foram retratados pelos versos de Knopfli; tempos em que os amanheceres banhados pela chuva, pelas sombras, pelos arrepios de medo, pela obscuridade, faziam dos sujeitos apenas coadjuvantes de um momento de dor; tempos nos quais os atores sociais não puderam ser de forma plena, não puderam sequer elevarem as suas vozes.

Nos versos do poema Dawn, a noite e o dia são uma imensa escuridão em meio ao silêncio:

\section{DAWN}

Agónica noite estremece

e despedaça-se

lá fora e chuva

nas vidraças.

Das sombras, das solidões

dos recantos recônditos

da noite e da chuva

saem homens

Pela crosta da terra passa

um frémito de arrepio.

Chove.

Chove em África.

É noite.

É noite em África.

Mão desmedida ergue-se

no breu,

corpo da terra que as águas

fecundam, impregnam.

Silêncios, hesitações, 


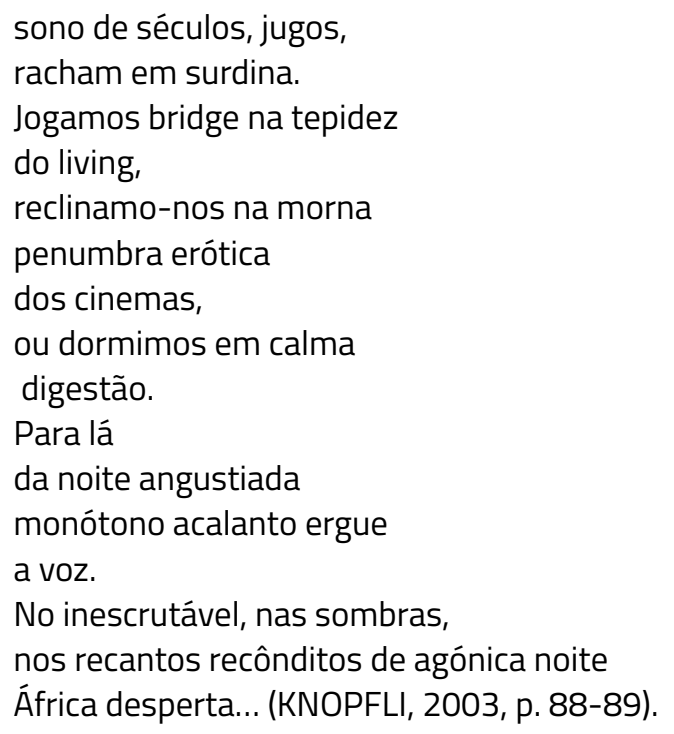

A palavra poética, nos versos dos poemas citados anteriormente, é reveladora da história, da agonia, da opressão simbólica, que nos desvela uma África e um sujeito abalados pelo sistema colonial. Nessa ordem, pensamos a poesia conforme Octavio Paz, quando diz que ela

nasce no silêncio e no balbuciamento, no não poder dizer, mas aspira irresistivelmente à recuperação da linguagem como uma realidade total. 0 poeta torna palavra tudo o que toca, sem excluir o silêncio [...] 0 poema acolhe o grito, os trapos vocabulares, a palavra gangrenada, o murmúrio, o ruído e o sem-sentido: não a in-significância (PAZ, 2009, p. 120).

Em Novo Testamento, o sujeito poético, em cada verso, nos golpeia com a ríspida realidade em que estava inserido o sujeito que vivia sob o jugo colonial, que só lhe restava o "eco distorcido das palavras" e viver com "o rosto emudecido", mas que ao regressar do sol em um novo recomeço, o sujeito vem a perceber, já em um momento de lucidez, porém cheio de mágoas, o sentido de si, dos outros e do mundo a sua volta. Buscando sua ressurreição, que é voltar a ser livre, livre pra soltar a voz a tanto tempo já embargada.

\section{Novo Testamento}

1

Sete dias de escuridão transfigurada em luz vivíssima.

Sete dias à beira da traição,

sem vezes vinte e quatro,

cento e sessenta e oito horas, 
precisamente $\mathrm{o}$ azeite da agonia que um relógio medonho marca gota

a gota

num tempo escamoteado à vida.

Sete círculos de inferno,

cento e setenta e oito vergastadas

e a coroa de dez mil e oitenta

espinhos dilacerando a voz

que conturbada se equilibra

nas arestas da loucura.

A cintilação catódica na penumbra

vacilante dos sangrados olhos

e os amortalhados vultos que apenas

lembram vagamente essoutra

humanidade autêntica. Digo Adeus

ao sono, despeço-me de mim.

Comovidamente abraço meu ódio.

2

Nada escuto já se não o eco

distorcido das palavras. Este,

o som humano que perdura,

corda vibrada na distância,

já não a voz, mas a modulação

que dela paira alheia, desambientada;

o efeito inocentado da causa,

o rosto emudecido, o som abrindo

em som, o som etéreo

descarnando o silêncio. 0 silêncio

percurtido fechando-se sobre o som

e o que sobra de um grito

esboroando-se de impotência

no visco silencioso dos carrascos.

3

Eis-te de borco, inerte, derrotado enfim, em tua álgida e anónima cruz de lajedo.

Eis-te supliciado, as carnes laceradas,

o rosto entumescido, violáceas as mãos.

Tua cruz mal principia mas a sombra

que projecta prossegue já além dos muros. 
Um vento mordente e salgado dobra as cristas do betão e pula arabescos magnéticos no tímido esboço da manhã, e põe lábios e frémitos e vozes ciciadas, nos quietos ângulos de pedra. Um vento endiabrado e desobediente rompe a correção, a vigília, a disciplina. 0 que é a verdade? Aí, estendido no silêncio do coma e na recusa das palavras, tu és a verdade.

\section{4}

0 regresso ao sol é o regresso ao princípio, porque o sol tem o brilho novo do princípio e as coisas têm o ar estranhamente fresco do primeiro dia da criação. E simplesmente um novo princípio um como que recomeço do tempo sob a vigilância de um olhar agora mais lúcido e magoado, um olhar que se demora e se organiza sobre os seres e os objetos, tacteando-lhes o sentido profundo e oculto. Os músculos e o sangue e os nervos reaprendem cautelosamente o caminho que os olhos desvendam no dia claro.

A liberdade é a ressurreição. (KNOPFLI, 2003, 178-180).

Nesses poemas, que têm o silenciamento e o obscurantismo como pano de fundo do contexto histórico, vemos o sujeito poético penetrar nos caminhos sombrios da memória, inicia o percurso estabelecendose em relação de igualdade com as vozes que se calaram e que compõem a sua expressão poética. De um lado há a voz silenciada; do outro, a do que silencia, notamos porém que o silenciamento não vem de modo direto, mas, nefastamente, através do não reconhecimento da audibilidade do outro. Essa situação é esclarecida no fragmento em que Orlandi trata sobre a política do silêncio em que

O mecanismo do silenciamento é um processo de contenção de sentidos e de asfixia do sujeito porque é um modo de não permitir que o sujeito circule pelas diferentes formações discursivas, pelo seu jogo. Com o apagamento de sentidos, há zonas de sentido, e, logo, posições do sujeito que ele não pode ocupar, que thes são interditadas. No caso do discurso da colonização, o sujeito colonizado não pode ocupar posições 
discursivas (com seus estatutos e sentidos) que o colonizador ocupa. Mais do que isso, é a partir das posições do colonizador que são projetadas as posições possiveis (e impossiveis) do colonizado. Seu dizer está assim predeterminado pela oposição do colonizador. (ORLANDI, 1990, p. 52).

O silêncio vai funcionar, ao mesmo tempo, como aquilo que apaga alguns sentidos e como produtor de resistência. Ao silenciar, podemos observar os fatos e nos negar a reproduzir determinado discurso ou apenas silenciar e não nos posicionarmos por medo da repressão. Desse modo, o silêncio intervém mostrando a falta de simetria entre os interlocutores.

O sujeito poético knopfliano articula-se com o silêncio e com o labor poético como forma de revelar a condição humana e a condição histórica de um momento estarrecedor. Porém, o silêncio aqui não é sinônimo apenas de estar calado, mas também é um espaço de pensamento, de introspecção, de contemplação.

\section{4 À GUISA DE CONSIDERAÇÕES FINAIS}

A obra poética de Rui Knopfli foi produzida parte no período da administração colonial portuguesa em Moçambique, parte no período pós-independência em Lisboa e em outros lugares da Europa por onde se exilou. É um caso ímpar na produção poética moçambicana, sendo um dos únicos escritores de ascendência europeia nascido em Moçambique, que pode ser incluído em uma leitura dentro dos parâmetros teóricos do discurso pós-colonial. Devemos entender sua obra nos complexos contexto e relação pós-colonial-luso-africanos, havendo na sua poética uma anunciação da queda e retirada do colonialismo português, bem como a intenção de devolver à África a herança cultural e geográfica devastadas pelo domínio colonialista, ao largo de séculos de implementação de um sistema espoliativo.

Muitas são as pesquisas em literatura que retratam o sujeito africano à época colonial e pósindependência, contudo, em sua maior parte são narrativas o objeto estudado, e as investigações buscam analisar o discurso literário representante da voz dos sujeitos subjugados em contraponto ao discurso do colonizador. Neste trabalho, porém, analisamos o discurso poético que retrata o sujeito que se manifesta no entremeio das duas culturas, e como a produção literária do poeta representa esse momento histórico tão crucial. Knopfli apresenta em sua obra este sujeito que, não sendo o negro escravizado nem o mestiço, passa, após o período de libertação do sistema colonialista, a sofrer por não fazer parte, incisivamente, da formação discursiva totalmente inserida na luta pela libertação do jugo europeu.

É este sujeito cindido e híbrido que vai aparecer na obra knopfliana que, ao sentir-se fora do lugar, se põe em marcha a um outro espaço que não se configura como oposição do seu ponto de partida, ficando assim, em uma outra margem - a terceira, confluindo com o que Bhabha (2007) chama de entre-lugar. 
Com essa configuração híbrida do sujeito, as formas culturais dominantes passam a ser "crioulizadas", havendo assim, conforme explica Hall (2003, p. 34-35), uma desarticulação de certos signos e rearticulação de outra forma cultural com outro significado simbólico. É o que ele chama de "nova cultura", que é advinda então dessas permeabilidades culturais do colonizador e do colonizado (pós-colonialismo), que não poderá ser pensada como um retrocesso ao lugar em que se estava antes, mas, sim, considerar que há "algo no meio", espaço da cultura em que o colonizado está submerso depois do pós-independência. É de suma importância acrescentar que não somente o colonizado está submerso, mas também o sujeito descendente de europeu, que nasceu em terras africanas, está inserido nesse entremeio cultural, o que pode ser observado no conjunto poético de Knopfli.

Em consonância com o que observa Bhabha (2007, p. 20), é crucial passar a focalizar momentos e processos culturais que são produzidos na articulação de diferenças culturais e pensar que esses entrelugares fornecem o terreno para a elaboração de estratégias de subjetivação, tanto singular quanto coletiva, que dão início a novos signos de identidade e criam lugares de colaboração e contestação, no processo que vai definir a própria ideia de sociedade. Trabalhar a partir do discurso poético knopfliano corrobora com essa estratégia à qual nos incita Bhabha: a de repensar os Estudos Culturais e literários, focalizando não somente no discurso opositor do binarismo colonizador/colonizado, mas fazendo emergir o discurso que está no entremeio dessa relação desigual; um terceiro espaço que se apresentará profícuo e confortável de ser habitado, se pensarmos em Bachelard (1998), e que oferecerá as condições para que o sujeito colonizado se enuncie e atribua sentido a si mesmo e a sua ordem imaginária.

Para entender essa forma de representação, é primordial compreender, conforme o autor, o que ele designa por lócus de enunciação, ou seja, o contexto e as condições sócio-históricas de produção e interpretação de um dado discurso. Esse lócus é atravessado por uma gama heterogênea de ideologias e valores sócio culturais que constituem os sujeitos, é o "terceiro espaço" em que todo discurso contraditório e conflitante de elementos linguísticos e culturais interagem, constituindo o hibridismo.

Bhabha (1996) fala-nos que esse sujeito, surgente das relações politico-culturais entre colonos e colonizados, é aquele que habita os entre-lugares e se apresenta de forma confusa, disseminada, sem pretensão à totalidade e se constitui na articulação de diferenças culturais. Não sendo homogêneo e previsivel, foge ao desejo do que antes no discurso colonialista era uma pretensão: tornar o sujeito totalmente dominável.

Verificamos, então, que o sujeito híbrido knopfliano, inserido em um primeiro momento em um contexto colonial e, depois, em um pós-independência, contra identifica-se com o discurso colonialista e na sua obra poética aparecem as marcas e os sentidos referentes a essa contra identificação. 
A temática do silêncio, da memória, o dialogismo com escritores ocidentais, o resgate do ambiente e natureza africanos, o sofrimento pelo não-pertencimento vão apresentar a materialidade poética do espaço que é característico do período pós-colonial, em que há um reflexo na escrita de uma interação entre língua, história e meio ambiente. 0 espaço criativo será o do conforto e o da memória, nele pode voltar em tempos e lugares, não há censuras e, desse modo, o sujeito passa pelo desafio do tempo e do espaço divisos, pela assincronia, busca a sua identidade e uma harmonia com uma identidade social, para tanto, utiliza recursos poéticos e artifícios que a literatura lhe propicia.

\section{REFERÊNCIAS}

AUGÉ, M. Por uma antropologia dos mundos contemporâneos. Rio de Janeiro: Bertrand Brasil, 1997. Não Lugares: Introdução a uma antropologia da supermodernidade. Campinas: Papirus, 2014. BACHELARD, G. A poética do espaço. São Paulo: Martins Fontes, 1998.

BHABHA, H. O Local da Cultura. Belo Horizonte: Editora da UFMG, 2007.

HALL, S. A Identidade Cultural na Pós-Modernidade. Rio de Janeiro: DP\&A Editora, 2011.

KNOPFLI, R. Obra Poética. Lisboa: Editorial da INCM, 2003.

ORLANDI, E. P. Terra à vista. Discurso do confronto: Velho e Novo mundo. São Paulo: Cortez Editora, 1990. . Destruição e construção do sentido: um estudo da ironia. In: Colóquio do Departamento de Linguística do IEL. Campinas: Editora da UNICAMP, 1983.

As Formas do Silêncio: No Movimento dos Sentidos. Campinas: Editora da UNICAMP, 1997.

PAZ, O. Signos em Rotação. São Paulo: Editora Perspectiva, 2009.

0 Arco e a Lira. São Paulo: Cosac Naify, 2012.

Os Filhos do Barro. São Paulo: Cosac Naify, 2013.

STEINER, George. Lenguaje y Silencio: ensayos sobre la literatura, el lenguaje y lo inhumano. Barcelona: Editorial Gedisa, 2003. 